\title{
Role of pericytes in angiogenesis: focus on cancer angiogenesis and anti-angiogenic therapy
}

\section{Minireview}

Z. CHEN, X. H. XU*, J. HU

Department of Oncology, The First College of Clinical Medical Science, China Three Gorges University \& Yichang Central People's Hospital, Yichang, China

*Correspondence: xuxinhua@medmail.com.cn

Received July 5, 2015 / Accepted September 14, 2015

Pericytes, a kind of mural cells for microcirculation, are critical for vascular development and function. Although current studies indicate that PDGF/PDGFR- $\beta$, Ang/Tie2, TGF- $\beta$ involve in the regulation of pericytes recruitment, the mechanisms governing pericytes migration and regulating angiogenesis, especially in cancers, have not been fully clear. Many evidences have showed that cancer vessels are characterized by abnormal pericyte coverage and altered pericytes-endothelial cells interactions, which contribute to the metastasis and progress of cancers. Therefore pericyte-targeting tend to be a promising anticancer therapy. Here we discuss the roles of pericytes in vasculatures and the effects of pericyte-targeting in anticancer treatment.

Key words: pericytes, angiogenesis, cancer

Pericytes, a kind of mural cells related to microvasculature, locate outside of the vasculature and often discontinuous embed in endothelial basement membrane [1]. There have various intercellular coactions between pericytes and endothelial cells (ECs), pericytes can coordinate other components of blood vessel wall to keep the progression of blood vessels, including the formation, maintenance and remodeling of blood vessels [2-4]. With further study, it's confirmed that pericytes play important roles in maintaining the stability of microvessel,

\footnotetext{
Abbreviations: Angiopoietin-1 - Ang-1; Alpha smooth muscle actin - aSMA; Activin receptor-like kinase - ALK; Angiopoietin-like protein 4 ANGPTL4; Endothelial cells - ECs; Extracellular matrixc - ECM; Heparan sulfate - HS; Hepatocyte growth factor - HGF; Lysophosphatidic acid - LPA; Matrix metalloproteinases - MMP; Monocyte chemoattractant protein-1 - MCP-1; Neuropilin-1 - NRP-1; Platelet-derived growth factor - PDGF; Platelet-derived growth factor receptor - PDGFR; Sphingosine 1-phosphate - S1P; Stromal-derived factor 1 alpha - SDF-1 $\alpha$; Tyrosine Kinase-2 - Tie2; Transforming growth factor $\beta$ - TGF- $\beta$; Vascular endothelial growth factor - VEGF; Vascular endothelial growth factor receptor - VEGFR; Vascular smooth muscle cell - vSMC
}

coordinating the function of ECs $[5,6]$, regulating blood flow [7], synthesis and release the structural materials of basement membrane or extracellular and modulating immune activity [8-10], pericyte-related contacts may provide a beneficial candidate for angiogenesis modulation [4]. Thus regulating pericytes function is likely to ameliorate vascular driven diseases such as cancers. Here we focus on the functions of pericytes during angiogenesis, and briefly summarize their values in anticancer therapy.

\section{Pericytes recruitment}

During angiogenesis, new tubes formed by ECs need the recruitment of pericytes and smooth muscle cells to provide a physical and chemical support for blood vessels, the recruitment of pericytes plays an important role in maintaining appropriate vascular morphogenesis. The pericytes coverage can be influenced by many factors, such as directly promote pericytes proliferation, directly protect pericytes from apoptosis, facilitate pericyte activation by releasing growth factors 
etc. Here we show some widely accepted mechanisms which controlled the recruitment of pericytes around ECs, including platelet-derived growth factor (PDGF)/PDGFR- $\beta$, Angiopoietin-1/Tyrosine Kinase-2 (Ang-1/Tie2), transforming growth factor $\beta$ (TGF- $\beta$ ), sphingosine 1-phosphate (S1P) and matrix metalloproteinases (MMP).

\section{PDGF/PDGFR- $\beta$}

PDGF/PDGFR- $\beta$, act as an important pathway which can promote the proliferation, migration, survival and vascular endothelial growth factor (VEGF) expression of cells, also occupy a significant position in promoting pericytes recruitment [11-13]. Some studies showed that the lack of PDGF or PDGFR- $\beta$ expression resulted in a failure of pericytes recruitment around to vessels [14-16]. When angiogenesis occurs, PDGF often will be released from angiogenic ECs ${ }^{[2]}$, then PDGF will bind to PDGFR- $\beta$ on pericytes and induce the proliferation and migration of pericytes $[17,18]$. However, the mechanisms underlying this recruitment remain obscure. Hamdan revealed that the expression of stromal-derived factor 1 alpha (SDF-1 $\alpha$ ) in ECs, which involved in the motility and differentiation of pericytes in vitro, could be induced by cancer-derived PDGF-BB. With further studies, they found that SDF-1 $\alpha / C X C R 4$ axis had a positive effect on PDGF-BBinduced pericyte recruitment $[19,20]$. Cancer cell-secreted PDGF-B also potentiate the mesenchymal stem cells-pericytes transition and control their recruitment via neuropilin-1 (NRP-1) signaling [21]. To be note, an in vitro study using mouse models, revealed that heparan sulfate (HS) with sufficiently extending and N-sulfated domains with appropriately spacing is required for PDGF/PDGFR- $\beta$ mediated pericyte recruitment [22].

\section{Ang-1/Ang-2/Tie2}

Ang-1 is known to be predominantly produced by vascular smooth muscle cell (vSMC) and pericytes [23]. It can be bind with Tie2 receptor, which is expressed mainly on endothelium, and maintain the maturation and stabilization of newly formed blood vessels [24], the stimulation of pericyte recruitment via Ang-1 signal contribute to the stabilization. Some findings suggested that Ang-1 could facilitate EC-dependent release of growth factors including TGF- $\beta$ and PDGF-B, leading to the promotion of pericytes recruitment [25-28]. Moreover, as a mediator of pericyte motility, hepatocyte growth factor (HGF )[29] also could be up-regulated by Ang-1/Tie2 signaling stimulation. Thus, Ang-1/Tie2 can act as a compensate signaling for pericyte recruitment. In contrary, Ang-2, which can compete with the binding of Ang-1 to Tie2, will be largely secreted when ECs are activated by cancer-derived modulators, then antagonise the function of Ang-1 [30]. Ang-2/Tie2 will induce loosening the attachment between ECs and pericytes and reduce pericytes coverage $[28,31]$.

\section{TGF- $\beta$}

TGF- $\beta$ is a main factor of pericyte and ECs proliferation, and mainly secreted by ECs [2]. The TGF- $\beta$ signaling is also required for the maintenance of vessels development [32]. Some findings showed that the absence TGF- $\beta$ activity will result in highly abnormal vasculature such as the lack of pericyte coverage, tortuous vessels and vessel hemorrhaging [33, 34]. The expression of alpha smooth muscle actin (aSMA), a widely accepted pericyte marker, also was related to the release of TGF- $\beta$ by ECs. The switch governance of $\alpha \mathrm{SMA}$ and NG2/desmin expression seemed dependent on TGF- $\beta$ [35]. It's known that the expression of specific TGF- $\beta$ receptor can modulate TGF- $\beta$-induced cell responses [36]. There are different kinds of TGF- $\beta$ receptors activin receptor-like kinase (ALK), such as ALK1 and ALK5, and they perform noteworthy opposite effects: ALK1 stimulates cells recruitment while ALK5 leads to the quiescence of cells $[37,38]$. Zhu showed that the decrease of ALK1 signaling and increase of ALK5 activity would result in disturbed endothelial proliferation, migration and differentiation as well as defective vascular smooth muscle cell recruitment and differentiation [39]. Chen indicated that ALK1 deficiency promote the impairment of vascular integrity even after VEGF stimulation. By using anti-ZIC1 and anti-NG2 antibodies to identify pericytes, they showed that the pericyte coverage was decreased [40]. Moreover, TGF has been found to possess the ability of facilitating the secretion of monocyte chemoattractant protein-1 (MCP-1) which can promote the recruitment of mural cells [ 41], and may lead the TGF- $\beta$-induced pericytes migration toward endothelium $[42,43]$.

\section{SIP}

S1P, a secreted sphingolipid that regulate cell communications through G-protein coupled receptors (EDG), is well known for its roles in modulation of ECs and mural cells proliferation, migration and interactions [44]. It can bind to five G protein coupled receptors named S1PR, S1P1-5, and play a critical role in vascular development via vascular $\mathrm{S} 1 \mathrm{P}$ receptors $[45,46]$. As the well-known pro-angiogenic factor, S1P-1 can regulate the vascular endothelial barrier via the modulation of extracellular matrixc (ECM) such as VE-cadherin and adherens junctions, and the mediation of mural-endothelial interactions $[47,48]$, subsequently may strengthen the association between ECs and pericytes. On the contrary, with the activation of S1P2-dependent pathways in LRP1-containing cells, the PDGF-BB induced cell migration could be downregulated by SIP [44]. Similarly, Du found that inhibiting S1P2 could enhance the recruitment of mural cells, and the induced-production of pro-angiogenic factors such as TGF- $\beta$, VEGF-A may contribute to it [49]. Interestingly, recent findings show that $\mathrm{S} 1 \mathrm{P} 1$ has a negative regulation in angiogenic sprouting [50]. Thus, the activity of different S1P receptors will lead to different responses to the migration and interaction of mural cells/ECs. 


\section{MMP}

MMPs, which can degrade the ECM and basement membrane, can be expressed by vascular smooth muscle cells as well as pericytes [51, 52]. Evidences suggested that brain pericytes were the major source of MMP-9 in blood-brain barrier, and the pericytes-derived MMP-9 would initiate pericytes migration $[53,54]$. Treated with SB-3CT, a selective inhibitor for gelatinases (MMP-2 and-9), the loss of laminin-positive pericytes could be reduced [55]. Christophe revealed that there was an inhibition in cancer vasculature architecture in MMP9-deficient mice, while these changes have a correlation with a $48 \%$ decrease in pericytes present along microvessels [56]. Many mechanisms or possibilities may explain the contribution of MMPs for pericyte recruitment: directly promoting pericyte invasion via ECM degradation; facilitating pericyte proliferation by modification of ECM; activating pericytes through the release of growth factors (such as VEGF) bound to the ECM; assisting the propagation of angiogenic signaling and recruiting bone marrow-derived cells [57-59].

\section{Pericytes in angiogenesis}

In the initial stage of angiogenesis, the dissociation of pericytes-ECs will occur when the formation of vascular tubes by ECs. It is well known that the degradation of vascular basement membrane is important for initial vascular tubes formation. Some evidences suggest that instead of MMPs production, the increase of pericyte-derived cathepsin activity result in the augment of vascular and the detachment of pericytes [60]. Besides, pericytes can secrete VEGF and subsequently play a critical role in pericytes-ECs dissociation. So new blood tubes will be formed via the proliferation and migration of ECs. But of note, the tubes are composed of ECs with immature basement membrane, the followed event is recruiting pericytes to promote the stability and maturity of vasculature.

With the advance of the progression, pericytes-ECs interaction will provide beneficial conditions for the survival and proliferation of ECs. The secretion of VEGF from pericytes, known as the most important pro-angiogensis factor, can promote ECs survival and proliferation. Franco uncovered that pericytes had the ability to induce the expression of Bcl-w, an antiapoptotic protein, in cancer ECs, contributing the survival of ECs. The activation of NF- $\mathrm{BB}$ in ECs signal transduction pathway can partly explain it [61]. Besides, VEGF and other pro-angiogensis factors can induce the production of MMP by pericytes, which lead to the promotion of ECs migration. Meanwhile, PDGF will be secreted from ECs, and facilitate more pericytes recruitment in turn. Interestingly, some studies confirmed that PDGF and VEGF had an antagonistic relationship in angiogenesis $[62,63]$. Recent findings also suggested that PDGFR- $\beta$ activity in mural cells might be modulated by VEGF. The most likely explanation is that the function of VEGF play a predominant role in earlier stage, then the PDGF-related modulation will be permitted.
When the angiogenic growth is sufficient in an area, the proliferation of ECs could be inhibited by pericytes to maintain new blood vessels stability. Through the Ang-1/Tie2, the inhibition of ECs activity could be induced. Ang-1 also belong to chemokine of ECs, it can prevent ECs from apoptosis under the lack of VEGF. On the other hand, ECs and smooth muscle cells can express Ang-2, act as a antagonistic factor for Ang-1 function, causing the unstabilization of ECs and the loss of pericyte recruitment [64]. So the modulation of Ang-1: Ang-2 ratio will influence the physiological progression of angiogenesis. Wakui showed that Ang-2 and VEGF could be increased in initiatory angiogenic phase, while in maturation phase might be initiated by relative enhancement of Ang-1 and decrease of VEGF [65]. Besides, some studies also showed that the enhancement of Rho GTPase signaling in pericytes contribute to the inhibition of adjacent ECs proliferation [66]; in an in vitro blood vessels model, which regression was driven by lysophosphatidic acid (LPA), Motiejūnaitè found that pericytes could induce the stabilization of ECs tubes via accelerating the metabolism of LPA [67].

Finally, the integrated structural support and physiological interactions of pericytes will generate the maturity of vasculatures $[19,68]$. Interestingly, Simonavicius demonstrated that pericytes could actively promote the destabilization and regression of selective vessel in vivo [3]. It's well known that the initial newly formed vascular plexus needs to be remodeled extensively, the selective branch regression can lead to unwanted capillaries pruning and promote the end of vessel plasticity.

\section{Pericytes in cancer}

It is well known that cancer vessels is patently abnormal and tends to adopt immature vascular phenotypes. Their fragility and leakage caused by abnormal basement membranes, impaired cell-to-cell attachment and leaky microvessels contribute to the increase of interstitial fluid pressure. The reduction of pericytes coverage and the perturbed associations between pericytes and ECs can partially explain them. We have found that pericytes are abnormal around cancer vasculatures $[69,70]$. They appears more disorderly arrangement, aberrant cell shapes, altered morphologies and marker expression and looser vessel attachment. They usually absent in cancer vasculatures and have loose associations with ECs. Thus, pericyte has been implicated as mediator of several cancer-related processes including cancer angiogenesis and metastasis [71, 72].

Hypoxia, which often occur in cancer, can effect pericytes via releasing a variety of factors, such as VEGF, Ang-2 and MMP $[73,74]$. During the cancer progression, frequent hypoxia can stimulate the secretion of VEGF by pericytes via HIF signal $[62,75]$. The relatively upregulation of VEGF may promote the development of cancer vasculature. With expression of pericyte-related Ang-2 and MMP caused by hypoxia, the destabilization of vessels and the increased permeability of 
endothelial barrier may be induced. Through the micro-array analysis of cortical pericytes miRNAs in rats with exposure to low oxygen and without low oxygen, Truettner found that the expression of $27 \mathrm{miRNAs}$ were higher and $31 \mathrm{miRNAs}$ were lower in hypoxia group, which related to the changes of angiogenesis, migration and cell cycle regulation [76]. So pericytes need to further study to develop possible cancer targets.

Metastasis is one main reason of patients death, while deficient pericytes of cancer vasculatures could be partly responsible for vascular metastasis $[77,78]$. Immature and leaky vessels, caused by pericytes deficiency, in cancers could increase cancer interstitial fluid pressure and enhance cancer cells flowing into vessels. Compared to lymph node carcinoma of the prostate cells (LNCaPs), the LNCaP-19 cells, a hypotype with more aggressive, present a lower pericyte coverage [79]. Poor pericyte coverage has also been confirmed that has correlation with worst prognosis for patients with invasive breast cancer [80]. Moreover, Zhou showed that through the production of Semaphorin 4D (SEMA4D) from cancer cells, the expression of PDGF-B and angiopoietin-like protein 4 (ANGPTL4) in ECs could be induced in a Plexin-B1/Rhodependent manner, thereby affecting the proliferation and differentiation of pericytes and vascular permeability [13].

To be note, Cao observed that higher pericyte coverage was related with more aggressive clinicopathologic characteristics in clear cell renal cell carcinoma patients [72]. Through pericytes genetic targeting in non-hypoxic (early stage) or hypoxic (advanced stage) cancers, Keskin indicated that the depletion of PDGFRb+ pericytes reduced metastasis at early stages, whereas it enhanced metastasis at later stages [28]. At early stage, the pericytes depletion may influence cancer's adequate energetic needs via disturbing vascular network, leading to the decrease of cancer growth and metastasis. With the increased depletion, it will result in the reduction of cancer blood vessels as well as the increase of blood permeability, which contribute to the enhancement of intratumoral hypoxia and cancer metastasis.

Pericytes also have the ability to affect cancer progression undergo lymphovascular invasion. Xian found that pericyte deficient mice accompanied with increased lymph node and distant organ metastasis Additionally, a novel mode of cancer spread has been found: termed "extravascular migratory metastasis". Cancer cells can migrate along the outer or abluminal surface of vessels. Some findings shown that melanoma cancer cells spread along the abluminal vascular surface in a pericytic location, without entering into vascular channels $[82,83]$. Perivascular migration or pericyte mimicry, a potential route of cancer spread, will provide novel target for cancer treatment.

Moreover, pericyte has been confirmed to involve in the modulation of immune activity $[8,84,85]$. Immune evasion is a critical factor for cancer growth, thus pericytes may influence the cancer progression in immune manner. Malignant gliomaderived pericyte has been evidenced that possess the capability to suppress T cell proliferation [86]. Bose demonstrated that cancer-derived pericytes had a negatively influence on CD4+ $\mathrm{T}$ cell activation and proliferation, they also had the ability to increase anergy in recall response to $\mathrm{Ag}$ by $\mathrm{CD} 4+\mathrm{CD} 44+$ $\mathrm{T}$ cells through regulating $\mathrm{G}$ protein signaling 5-and IL-6dependent pathways [9].

\section{Pericyte-targeted treatment}

The anti-angiogenesis field is a major force in modern medicine for various cancers. However, increasing studies have shown that targeting ECs, VEGF signaling alone is not sufficient for effective cancer control [87]. There are cancer vessels subsets which don't rely upon VEGF for maintenance [88]. Thus pericytes have emerged as a significant target for anti-angiogenic therapy.

One hand, enlarging the coverage of pericytes around cancer vasculature could induce the normalize of cancer vasculatures. Thereby, the interstitial fluid pressure and permeability of intratumoral blood vessels will be recovered [73, 89], leading to the prevention of cancer cells disseminating into circulation and the increase of perfusion and oxygenation in cancer to enhance therapy effects [90-92]. Besides, pericytes may restrict the formation of new cancer vessel cavity and maintain the stability of cancer vessels, subsequently inhibit cancer growth due to the limitation of blood supply. Many works has showed that anti-VEGF therapy may result in the "normalization of cancer vasculature", including increase pericytes coverage, and result in increased regions of necrosis in cancer [93].

Through establishing a stable mice mode with PDGF-BB overexpression in colorectal cancer and pancreatic cancer cells, Mccarty observed the increased pericyte coverage as well as marked inhibition of cancer growth, with the treatment of imatinib mesylate (PDGFR inhibitor), the growth could be increased and the total pericyte content could be decreased, compared to untreated cancers [94]. In addition to, enhancing pericytes-ECs interaction such as Ang-2/tie2 signal also act as an important role in cancer treatment. Falcon showed that inhibition of Ang-2, the antagonistic factor of Ang-1, could induce the reduction of cancer growth and keep constant vascular density [95]. Through comparative analysis of cancers growth in wild-type (WT) and Ang-2-deficient mice, Nasarre indicated that the cancer growth in Ang-2-deficient mice was slower than in WT mice, as well as the cancer microvessels in Ang-2-deficient mice were more plentifully covered by more mature pericytes. It's worth noting that the growth difference in two kinds mice models occurred during early stages of cancer development [64].

On the other hand, high level pericytes coverage contribute to the poorer outcomes, some studies have shown that increased PDGFR- $\beta$ expression, an important promoter for pericytes recruitment, can act as an independent predictor of short disease-specific survival in cancers [80, 96, 97]. Reducing pericytes can enhance the effect of anti-cancer therapies through many mechanisms. As we all known, VEGF can 
stimulate the survival and proliferation of ECs, while pericytes can protect ECs from the withdrawal of VEGF via producing VEGF, therefore may result in pericyte-induced resistance to anti-angiogenic therapy. Besides, the Ang- 1 expression and the binding of PDGF to PDGFR- $\beta$ in pericytes also play significant roles in maintain the stabilization of cancer vessels. Once inhibited the pericytes recruitment or disrupted the pericytesECs association, the response to anti-cancer therapies may be increased via inhibiting the formation of new cancer vessels and reducing cancer blood supply.

Some studies proved that imatinib could mediate antiangiogenesis in lymphoma model via inhibiting the function of PDGFRb1 pericyte, resulting in significant inhibition of human lymphoma growth [98]. As it is said above, single antiangiogenic strategies often have provided limited response, some trials showed that PDGFR- $\beta$ blockade (via imatinib) alone could not provide benefits for cancers outcomes [99, 100]. The combination of anti-angiogenic agents or multipleinhibitor will be a trend in anti-cancer treatment. Some evidences showed that simultaneously targeting VEGFR, PDGFR- $\beta$ and fibroblast growth factor receptor could result in remarkable inhibit the growth and angiogenesis of cancers [101]. Dual VEGFR/PDGFR- $\beta$ inhibition appeared more benefit in ovarian cancer compared with single receptor-inhibition $[102,103]$. Abou-Alfa found that combination of Sorafenib, an inhibitor of VEGFR, PDGFR- $\beta$, Kit and Flt3, and doxorubic couldimprove the treatment efficacy of hepatocellular carcinoma, versus doxorubicin alone [104]. In a phase 3 trial, Raymond found that continuous daily administration of sunitinib, a general receptor tyrosine kinase inhibitor that target VEGFR and PDGFR- $\beta$, at a dose of $37.5 \mathrm{mg}$ could improve the progression-free survival, overall survival and the objective response rate in patients with pancreatic neuroendocrine cancers compared to placebo [105], it also provided benefits for outcomes of unresectable hepatocellular carcinoma [106]. Similarly, regorafenib, a multiple-inhibitor, can improve the the outcomes of colorectal cancer patients who fail with VEGFR inhibitor therapy [107]. Some evidences also suggested that the synergy between PDGFR- $\beta$ and VEGFR mainly depended upon the strength of VEGF blockade. To note, some studies also suggested that additional targeting of pericytes didn't promote the effect already generated by VEGF inhibitor [108].

Besides, considering the physical location of pericytes, which often locate at ECs junctions and cover gaps between ECs, pericytes-ECs will shield cancer cells from damaging factors, such as immune cells $[86,9,109]$ and chemotherapy drugs. Wang found that pericytes-derived Ang-1 could upregulate the expression of tight junction proteins zona occludens (ZO)-1 and occluding [110]. The upregulation of adhesion proteins and $\mathrm{N}$-cadherin induced from pericytes may involve in the enhancement of barrier function [111]. Pericytes also enhance the function of tight junction or endothelial barrier via various molecular mechanisms $[112,113]$. Therefore, targeting pericytes and ECs may enhance the abrogation of pericytes-ECs shield around localized cancer cells and allowed more easy to reach targets. Ruan suggested that imatinib impaired the growth of lymphoma, not only by influencing the pericytes coverage, but also by weakening the cancer stromal compartment [114].

\section{Conclusion}

Pericytes receive increasing attention due to their vital role in vasculature development. With the sufficient coverage of pericytes and the normal connections between ECs and pericytes, the stable and mature vessel structure/function can be formed. Due to the pericytes coverage and pericytes-ECs interactions are often abnormal in cancer-related vasculatures, targeting pericytes would be a important mode for anti-cancer treatment. On the one hand, the restoration of normal pericytes coverage and function may enhance cancers responses to chemo and radiation therapies via maintaining the normalization of cancer vasculature, including increasing the perfusion and oxygenation of located cancer. On the other hand, targeting pericytes can enhance the effect of anti-cancer therapies, especially in combination with antiangiogenic agents such as VEGF inhibitors. Although many evidences suggest that pericyte-target treatments provide benefit for anti-cancer, further researches are needed to set more effective and reasonable therapy scheme, including decrease the side effects in multiple-agents antiangiogenic therapy [115]; develop novel and specific pericyte-related agents; choose prioritized mode, especially choose better mode (increasing the pericytes recruitment or reducing pericytes) in different cancers and different stages. With these efforts a better cancer control would be achieved.

\section{References}

[1] DORE-DUFFY P, CLEARY K. Morphology and properties of pericytes. Methods Mol Biol 2011; 686: 49-68. http://dx.doi. org/10.1007/978-1-60761-938-3 2

[2] ARMULIK A, GENOVE G, BETSHOLTZ C. pericytes: developmental, physiological, and pathological perspectives, problems, and promises. Dev Cell 2011; 21: 193-215. http:// dx.doi.org/10.1016/j.devcel.2011.07.001

[3] SIMONAVICIUS N, ASHENDEN M, VAN WEVERWIJK A, LAX S, HUSO DL et al. Pericytes promote selective vessel regression to regulate vascular patterning. Blood 2012; 120: 1516-1527. http://dx.doi.org/10.1182/blood-2011-01$\underline{332338}$

[4] LIN J, LEMKE C, REDIES C, YAN X, MIX E et al. ADAM17 overexpression promotes angiogenesis by increasing blood vessel sprouting and pericyte number during brain microvessel development. Int J Dev Biol 2011; 55: 961-968. http:// dx.doi.org/10.1387/ijdb.103210j1

[5] GORDON MS, MENDELSON DS, KATO G. Tumor angiogenesis and novel antiangiogenic strategies. Int J Cancer 2010; 126: 1777-1787. http://dx.doi.org/10.1002/ijc.25026

[6] CHANG WG, ANDREJECSK JW, KLUGER MS, SALTZMAN WM, POBER JS. Pericytes modulate endothelial 
sprouting. Cardiovasc Res 2013; 100: 492-500. http://dx.doi. org $/ 10.1093 / \mathrm{cvr} / \mathrm{cvt} 215$

[7] HALL CN, REYNELL C, GESSLEIN B, HAMILTON NB, MISHRA A et al. Capillary pericytes regulate cerebral blood flow in health and disease. Nature 2014 ; 508: 55-60. http:// dx.doi.org/10.1038/nature13165

[8] PROEBSTL D, VOISIN MB, WOODFIN A, WHITEFORD J, D'ACQUISTO F et al. Pericytes support neutrophil subendothelial cell crawling and breaching of venular walls in vivo. J Exp Med 2012; 209: 1219-1234. http://dx.doi.org/10.1084/ jem.20111622

[9] BOSE A, BARIK S, BANERJEE S, GHOSH T, MALLICK A et al. Tumor-derived vascular pericytes anergize Th cells. J Immunol 2013; 191: 971-981. http://dx.doi.org/10.4049/ jimmunol.1300280

[10] DALKARA T, ALARCON-MARTINEZ L. Cerebral microvascular pericytes and neurogliovascular signaling in health and disease. Brain Res 2015. http://dx.doi.org/10.1016/j. brainres.2015.03.047

[11] CHATTERJEE S, NAIK UP. Pericyte-endothelial cell interaction: a survival mechanism for the tumor vasculature. Cell Adh Migr 2012; 6: 157-159. http://dx.doi.org/10.4161/ cam.20252

[12] LUK K, BOATMAN S, JOHNSON KN, DUDEK OA, RISTAU N et al. Influence of morphine on pericyte-endothelial interaction: implications for antiangiogenic therapy. J Oncol 2012; 2012: 458385. http://dx.doi.org/10.1155/2012/458385

[13] ZHOU H, YANG YH, BASILE JR. The Semaphorin 4DPlexin-B1-RhoA signaling axis recruits pericytes and regulates vascular permeability through endothelial production of PDGF-B and ANGPTL4. Angiogenesis 2014; 17: 261-274. http://dx.doi.org/10.1007/s10456-013-9395-0

[14] BERTHOD F, SYMES J, TREMBLAY N, MEDIN JA, AUGER FA. Spontaneous fibroblast derived pericyte recruitment in a human tissue-engineered angiogenesis model in vitro. J Cell Physiol 2012; 227: 2130-2137. http://dx.doi.org/10.1002/ icp. 22943

[15] RIBATTI D, NICO B, CRIVELLATO E. The role of pericytes in angiogenesis. Int J Dev Biol 2011; 55: 261-268. http://dx.doi. org/10.1387/ijdb.103167dr

[16] STRATMAN AN, SCHWINDT AE, MALOTTE KM, DAVIS GE. Endothelial-derived PDGF-BB and HB-EGF coordinately regulate pericyte recruitment during vasculogenic tube assembly and stabilization. Blood 2010; 116: 4720-4730. http:// dx.doi.org/10.1182/blood-2010-05-286872

[17] GENOVE G, MOLLICK T, JOHANSSON K. Photoreceptor degeneration, structural remodeling and glial activation: a morphological study on a geneticmouse model for pericyte deficiency. Neuroscience 2014; 279: 269-284. http://dx.doi. org/10.1016/j.neuroscience.2014.09.013

[18] SUNDBERG C, FRIMAN T, HECHT LE, KUHL C, SOLOMON KR. Two different PDGF beta-receptor cohorts in human pericytes mediate distinct biological endpoints. Am J Pathol 2009; 175: 171-189. http://dx.doi.org/10.2353/ ajpath.2009.080769

[19] SONG N, HUANG Y, SHI H, YUAN S, DING Y et al. Overexpression of platelet-derived growth factor-BB increases tumor pericyte content via stromal-derived factor-1alpha/ CXCR4 axis. Cancer Res 2009; 69: 6057-6064. http://dx.doi. org/10.1158/0008-5472.CAN-08-2007

[20] HAMDAN R, ZHOU Z, KLEINERMAN ES. Blocking SDF-1 $\alpha / C X C R 4$ downregulates PDGF-B and inhibits bone marrow-derived pericyte differentiation and tumor vascular expansion in Ewing tumors. Mol Cancer Ther 2014; 13: 483491. http://dx.doi.org/10.1158/1535-7163.MCT-13-0447

[21] DHAR K, DHAR G, MAJUMDER M, HAQUE I, MEHTA S et al. Tumor cell-derived PDGF-B potentiates mouse mesenchymal stem cells-pericytes transition and recruitment through an interaction with NRP-1. Mol Cancer 2010; 9: 209. http:// dx.doi.org/10.1186/1476-4598-9-209

[22] ABRAMSSON A, KURUP S, BUSSE M, YAMADA S, LINDBLOM P et al. Defective N-sulfation of heparan sulfate proteoglycans limits PDGF-BB binding and pericyte recruitment invascular development. Genes Dev 2007; 21: 316-331. http://dx.doi.org/10.1101/gad.398207

[23] BUCHANAN CF, SZOT CS, WILSON TD, AKMAN S, METHENY-BARLOW LJ et al. Cross-talk between endothelial and breast cancer cells regulates reciprocal expression of angiogenic factors in vitro. J Cell Biochem 2012; 113: 1142-1151. http://dx.doi.org/10.1002/jcb.23447

[24] CHAKROBORTY D, SARKAR C, YU H, WANG J, LIU Z et al. Dopamine stabilizes tumor blood vessels by up-regulating angiopoietin 1 expression in pericytes and Kruppel-like factor-2 expression in tumor endothelial cells. Proc Natl Acad Sci USA 2011; 108: 20730-5. http://dx.doi.org/10.1073/ pnas. 1108696108

[25] AUGUSTIN HG, KOH GY, THURSTON G, ALITALO K. Control of vascular morphogenesis and homeostasis through the angiopoietin-Tie system. Nat Rev Mol Cell Biol 2009;10: 165-177. http://dx.doi.org/10.1038/nrm2639

[26] GAENGEL K, GENOVE` G, ARMULIK A, BETSHOLTZ C. Endothelial mural cell signaling in vascular development and angiogenesis. Arterioscler. Thromb Vasc Biol 2009; 29: 630-638. http://dx.doi.org/10.1161/ATVBAHA.107.161521

[27] FUXE J, TABRUYN S, COLTON K, ZAID H, ADAMS A et al. Pericyte requirement for anti-leak action of angiopoietin-1 and vascular remodeling in sustained inflammation. Am J Pathol 2011; 178: 2897-2909. http://dx.doi.org/10.1016/j. ajpath.2011.02.008

[28] KESKIN D, KIM J, COOKE VG, WU CC, SUGIMOTO $\mathrm{H}$ et al. Targeting vascular pericytes in hypoxic tumors increases lung metastasis via angiopoietin-2. Cell Rep 2015; 10 : 1066-1081. http://dx.doi.org/10.1016/j.celrep.2015.01.035

[29] YU X, RADULESCU A, CHEN CL, JAMES IO, BESNER GE. Heparin-binding EGF-like growth factor protects pericytes from injury. J Surg Res 2012; 172: 165-176. http://dx.doi. org/10.1016/j.jss.2010.07.058

[30] CHAE SS, KAMOUN WS, FARRAR CT, KIRKPATRICK ND, NIEMEYER E et al. Angiopoietin-2 interferes with antiVEGFR2-induced vessel normalization and survival benefit in mice bearinggliomas. Clin Cancer Res 2010 ; 16: 3618-3627. http://dx.doi.org/10.1158/1078-0432.CCR-09-3073

[31] FAGIANI E, LORENTZ P, KOPFSTEIN L, CHRISTOFORI G. Angiopoietin-1 and -2 exert antagonistic functions in tumor 
angiogenesis, yet both induce lymphangiogenesis. Cancer Res 2011;71: 5717-5727. http://dx.doi.org/10.1158/0008-5472. CAN-10-4635

[32] SEKI T, HONG KH, OH SP. Nonoverlapping expression patterns of ALK1 and ALK5 reveal distinct roles of each receptor in vascular development. Lab Invest 2006; 86: 116-129. http:// dx.doi.org/10.1038/labinvest.3700376

[33] THALGOTT J, DOS-SANTOS-LUIS D, LEBRIN F. Pericytes as targets in hereditary hemorrhagic telangiectasia. Front Genet 2015; 6: 37. http://dx.doi.org/10.3389/ fgene.2015.00037

[34] VAN DER MEER AD, ORLOVA VV, TEN DIJKE P, VAN DEN BERG A, MUMMERY CL. Three-dimensional cocultures of human endothelial cells and embryonic stem cell-derived pericytes inside a microfluidic device. Lab Chip 2013; 13: 3562-3568. http://dx.doi.org/10.1039/c3lc50435b

[35] SONG S, EWALD AJ, STALLCUP W, WERB Z, BERGERS G. PDGFRbeta(+) perivascular progenitor cells in tumours regulate pericyte differentiation and vascular survival. Nat Cell Biol 2005; 7: 870-879. http://dx.doi.org/10.1038/ncb1288

[36] ORLOVA VV, LIU Z, GOUMANS MJ, TEN DIJKE P. Controlling angiogenesis by two unique TGF- $\beta$ type I receptor signaling pathways. Histol Histopathol 2011; 26: 1219-1230.

[37] LEBRIN F, DECKERS M, BERTOLINO P, TEN DIJKE P. TGF-beta receptor function in the endothelium. Cardiovasc Res 2005; 65: 599-608. http://dx.doi.org/10.1016/j. cardiores.2004.10.036

[38] VAN GEEST RJ, KLAASSEN I, VOGELS IM, VAN NOORDEN CJ, SCHLINGEMANN RO. Differential TGF\{beta\{ signaling in retinal vascular cells: a role in diabetic retinopathy?. Invest Ophthalmol vis Sci 2010; 51: 1857-1865. http://dx.doi.org/10.1167/iovs.09-4181

[39] ZHU Q, KIM YH, WANG D, OH SP, LUO K. SnoN facilitates ALK1-Smad1/5 signaling during embryonic angiogenesis. J Cell Biol 2013; 202: 937-950. http://dx.doi.org/10.1083/ jcb.201208113

[40] CHEN W, GUO Y, WALKER EJ, SHEN F, JUN K et al. Reduced mural cell coverage and impaired vessel integrity after angiogenic stimulation in the Alk1-deficient brain. Arterioscler Thromb Vasc Biol 2013; 33: 305-310. http://dx.doi. org/10.1161/ATVBAHA.112.300485

[41] QIAN BZ, LI J, ZHANG H, KITAMURA T, ZHANG J et al. CCL2 recruits inflammatory monocytes to facilitate breast tumour metastasis. Nature 2011; 475: 222-225. http://dx.doi. org/10.1038/nature 10138

[42] HUANG C, DAY ML, PORONNIK P, POLLOCK CA, CHEN XM. Inhibition of KCa3.1 suppresses TGF- $\beta 1$ induced MCP-1 expression in human proximal tubular cells through Smad3, p28 and ERK1/2 signaling pathways. Int J Biochem Cell Biol 2014; 47: 1-10. http://dx.doi.org/10.1016/j. biocel.2013.11.017

[43] WILSON TJ, NANNURU KC, FUTAKUCHI M, SINGH RK. Cathepsin G-mediated enhanced TGF-beta signaling promotes angiogenesis via upregulation of VEGF and MCP-1. Cancer Lett 2010; 288: 162-169. http://dx.doi.org/10.1016/j. canlet.2009.06.035
[44] NAKAJIMA C, HAFFNER P, GOERKE SM, ZURHOVE K, ADELMANN G et al. The lipoprotein receptor LRP1 modulates sphingosine-1-phosphate signaling and is essential for vasculardevelopment. Development 2014; 141: 4513-4525. http://dx.doi.org/10.1242/dev.109124

[45] MENDELSON K, ZYGMUNT T, TORRES-VAZQUEZ J, EVANS T, HLA T. Sphingosine 1-phosphate receptor signaling regulates proper embryonic vascular patterning. J Biol Chem 2013; 288: 2143-2156. http://dx.doi.org/10.1074/jbc. $\underline{\mathrm{M} 112.427344}$

[46] TAKABE K, YAMADA A, RASHID OM, ADAMS BJ, HUANG WC et al. Twofer anti-vascular therapy targeting sphingosine-1-phosphate for breast cancer. Gland Surg 2012; 1: 80-83.

[47] TOBIA C, CHIODELLI P, NICOLI S, DELL'ERA P, BURASCHI S et al. Sphingosine-1-phosphate receptor-1 controls venous endothelial barrier integrity in zebrafish. Arterioscler Thromb Vasc Biol 2012; 32: e104-116. http://dx.doi. org/10.1161/ATVBAHA.112.250035

[48] SCHUCHARDT M, TOLLE M, PRUFER J, VAN DER GIET M. Pharmacological relevance and potential of sphingosine 1-phosphate in the vascular system. Br J Pharmacol 2011; 163: 1140-62. http://dx.doi.org/10.1111/j.1476-5381 .2011.01260.x

[49] DU W, TAKUWA N, YOSHIOKA K, OKAMOTO Y, GONDA $\mathrm{K}$ et al. S1p(2), the g protein-coupled receptor for sphingosine1-phosphate, negatively regulates tumor angiogenesis and tumor growth in vivo in mice. Cancer Res 2010; 70: 772-781. http://dx.doi.org/10.1158/0008-5472.CAN-09-2722

[50] BEN SHOHAM A, MALKINSON G, KRIEF S, SHWARTZ Y, ELY Y et al. S1P1 inhibits sprouting angiogenesis during vascular development. Development 2012; 139: 3859-3869. http://dx.doi.org/10.1242/dev.078550

[51] MACHIDA T, TAKATA F, MATSUMOTO J, TAKENOSHITA H, KIMURA I et al. Brain pericytes are the most thrombin-sensitive matrix metalloproteinase-9-releasing cell type constituting theblood-brain barrier in vitro. Neurosci Lett 2015; 599: 109-114. http://dx.doi.org/10.1016/j. neulet.2015.05.028

[52] THANABALASUNDARAM G, SCHNEIDEWIND J. The impact of pericytes on the blood-brain barrier integrity depends critically on the pericyte differentiation stage. Int J Biochem Cell Biol 2011; 43: 1284-1293. http://dx.doi.org/10.1016/j. biocel.2011.05.002

[53] TAKATA F, DOHGU S, MATSUMOTO J, TAKAHASHI H, MACHIDA T et al. Brain pericytes among cells constituting the blood-brain barrier are highly sensitive to tumor necrosis factor- $\alpha$, releasing matrix metalloproteinase- 9 and migrating in vitro. J Neuroinflammation 2011; 8: 106. http://dx.doi. org/10.1186/1742-2094-8-106

[54] TAKAHASHI Y, MAKI T, LIANG AC, ITOH K, LOK J et al. p38 MAP kinase mediates transforming-growth factor-1induced upregulation of matrix metalloproteinase- 9 but not -2 in human brain pericytes. Brain Res 2014; 1593: 1-8. http:// dx.doi.org/10.1016/j.brainres.2014.10.029

[55] CUI J, CHEN S, ZHANG C, MENG F, WU W et al. Inhibition of MMP-9 by a selective gelatinase inhibitor protects 
neurovasculature from embolic focal cerebralischemia. Mol Neurodegener 2012; 7: 21. http://dx.doi.org/10.1186/17501326-7-21

[56] CHANTRAIN CF, SHIMADA H, JODELE S, GROSHEN $\mathrm{S}$, YE W et al. Stromal matrix metalloproteinase-9 regulates the vascular architecture in neuroblastoma by promoting pericyterecruitment. Cancer Res 2004; 64: 1675-1686. http:// dx.doi.org/10.1158/0008-5472.CAN-03-0160

[57] CHANTRAIN CF, HENRIET P, JODELE S, EMONARD $\mathrm{H}$, FERON $\mathrm{O}$ et al. Mechanisms of pericyte recruitment in tumour angiogenesis: a new role for metalloproteinases. Eur J Cancer 2006; 42: 310-318. http://dx.doi.org/10.1016/j. ejca.2005.11.010

[58] JODELE S, CHANTRAIN CF, BLAVIER L, LUTZKO C, CROOKS GM et al. The contribution of bone marrowderived cells to the tumor vasculaturein neuroblastoma is matrixmetalloproteinase-9 dependent. Cancer Res 2005; 65: 3200-3208.

[59] THANABALASUNDARAM G, PIEPER C, LISCHPER M, GALLA HJ. Regulation of the blood-brain barrier integrity by pericytes via matrix metalloproteinases mediated activation of vascular endothelial growth factor in vitro. Brain Res 2010; 1347: 1-10. http://dx.doi.org/10.1016/j.brainres.2010.05.096

[60] CHANG SH, KANASAKI K, GOCHEVA V, BLUM G, HARPER J et al. Vegf-a induces angiogenesis by perturbing the cathepsincysteine protease inhibitor balance in venules, causing basement membrane degradation and mother vessel formation. Cancer Res 2009; 69: 4537-4544. http://dx.doi. org/10.1158/0008-5472.CAN-08-4539

[61] FRANCO M, ROSWALL P, CORTEZ E, HANAHAN D, PIETRAS K. Pericytes promote endothelial cell survival through induction of autocrine VEGF-A signaling and Bcl-w expression. Blood 2011; 118: 2906-2917. http://dx.doi.org/10.1182/ blood-2011-01-331694

[62] GREENBERG JI, SHIELDS DJ, BARILLAS SG, ACEVEDO LM, MURPHY E et al. A role for VEGF as a negative regulator of pericyte function and vessel maturation. Nature 2008; 456: 809-813. http://dx.doi.org/10.1038/nature07424

[63] BANFI A, VON DEGENFELD G, GIANNI-BARRERA R, REGINATO S, MERCHANT MJ et al. Therapeutic angiogenesis due to balanced single-vector delivery of VEGF and PDGF-BB. FASEB J 2012; 26: 2486-2497. http://dx.doi. org/10.1096/fj.11-197400

[64] NASARRE P, THOMAS M, KRUSE K, HELFRICH I, WOLTER V et al. Host-derived angiopoietin-2 affects early stages of tumor development and vessel maturation but is dispensablefor later stages of tumor growth. Cancer Res 2009; 69: 1324-1333. http://dx.doi.org/10.1158/0008-5472.CAN-08$\underline{3030}$

[65] WAKUI S, YOKOO K, MUTO T, SUZUKI Y, TAKAHASHI $\mathrm{H}$ et al. Localization of Ang-1, -2, Tie-2, and VEGF expression at endothelial pericyte interdigitation in rat angiogenesis. Lab Invest 2006; 86: 1172-1184. http://dx.doi.org/10.1038/ labinvest.3700476

[66] KUTCHER ME, KOLYADA AY, SURKS HK, HERMAN IM. Pericyte Rho GTPase mediates both pericyte contractile phenotype and capillary endothelial growth state. Am
J Pathol 2007;171: 693-701. http://dx.doi.org/10.2353/ ajpath.2007.070102

[67] MOTIEJUNAITE R, ARANDA J, KAZLAUSKAS A. Pericytes prevent regression of endothelial cell tubes by accelerating metabolism of lysophosphatidic acid. Microvasc Res 2014; 93: 62-71. http://dx.doi.org/10.1016/j.mvr.2014.03.003

[68] LEDERLE W, LINDE N, HEUSEL J, BZYL J, WOENNE EC et al. Platelet-derived growth factor-B normalizes micromorphology and vessel function in vascular endothelial growth factor-A-induced squamous cell carcinomas. Am. J. Pathol 2010; 176: 981-994. http://dx.doi.org/10.2353/ ajpath.2010.080998

[69] RAZA A, FRANKLIN MJ, DUDEK AZ. Pericytes and vessel maturation during tumor angiogenesis and metastasis. Am J Hematol 2010; 85: 593-598. http://dx.doi.org/10.1002/ ajh. 21745

[70] SUN H, GUO D, SU Y, YU D, WANG Q et al. Hyperplasia of pericytes is one of the main characteristics of microvascular architecture in malignant glioma. PLoS One 2014; 9: e114246. http://dx.doi.org/10.1371/journal.pone.0114246

[71] ANFUSO CD, MOTTA C, GIURDANELLA G, ARENA V, ALBERGHINA $M$ et al. Endothelial PKCa-MAPK/ ERK-phospholipase A2 pathway activation as a response of glioma in a triple culture model. A new role for pericytes? Biochimie 2014; 99: 77-87. http://dx.doi.org/10.1016/j. biochi.2013.11.013

[72] CAO Y, ZHANG ZL, ZHOU M, ELSON P, RINI B et al. Pericyte coverage of differentiated vessels inside tumor vasculature is an independent unfavorable prognostic factor for patients with clear cell renal cell carcinoma. Cancer 2013; 119: 313-324. http://dx.doi.org/10.1002/cncr.27746

[73] RIGAMONTIN, KADIOGLU E, KEKLIKOGLOU I, WYSER RMILI C, LEOW CC et al. Role of angiopoietin-2 in adaptive tumor resistance to VEGF signaling blockade. Cell Rep 2014; 8: 696-706. http://dx.doi.org/10.1016/j.celrep.2014.06.059

[74] SKULI N, MAJMUNDAR AJ, KROCK BL, MESQUITA RC, MATHEW LK et al. Endothelial HIF-2a regulates murine pathological angiogenesis and revascularization processes. J Clin Invest 2012; 122: 1427-1443. http://dx.doi.org/10.1172/ LCI57322

[75] TREVI-O-VILLARREAL JH, COTANCHE DA, SEPULVEDA R, BORTONI ME, MANNEBERG O et al. Host-derived pericytes and Sca-1+ cells predominate in the MART-1stroma fraction of experimentally induced melanoma. J Histochem Cytochem 2011; 59: 1060-1075. http://dx.doi. org/10.1369/0022155411428078

[76] TRUETTNER JS, KATYSHEV V, ESEN-BILGIN N, DIETRICH WD, DORE-DUFFY P. Hypoxia alters MicroRNA expression in rat cortical pericytes. Microrna 2013; 2: 32-44. http://dx.doi.org/10.2174/2211536611302010005

[77] STREMITZER S, ZHANG W, YANG D, NING Y, STINTZING $S$ et al. Genetic variations in angiopoietin and pericyte pathways and clinical outcome in patients with resected colorectal liver metastases. Cancer 2015; 121: 1898-1905. http://dx.doi.org/10.1002/cncr.29259

[78] MAZZIERI R, PUCCI F, MOI D, ZONARI E, RANGHETTI A et al. Targeting the ANG2/TIE2 axis inhibits 
tumor growth and metastasis by impairing angiogenesis and disabling rebounds of proangiogenic myeloid cells. Cancer Cell 2011; 19: 512-526. http://dx.doi.org/10.1016/j. ccr.2011.02.005

[79] WELEN K, JENNBACKEN K, TESAN T, DAMBER JE. Pericyte coverage decreases invasion of tumour cells into blood vessels in prostate cancer xenografts. Prostate cancer and prostatic diseases 2009; 12: 41-46. http://dx.doi.org/10.1038/ pcan.2008.33

[80] COOKE VG, LEBLEU VS, KESKIN D, KHAN Z, O'CONNELL JT et al. Pericyte depletion results in hypoxia-associated epithelial-to-mesenchymal transition and metastasis mediated by met signaling pathway. Cancer Cell 2012; 21: 66-81. http://dx.doi.org/10.1016/j.ccr.2011.11.024

[81] XIAN X, HÅKANSSON J, STÅHLBERG A, LINDBLOM P, BETSHOLTZ C et al. Pericytes limit tumor cell metastasis. J Clin Invest 2006; 116: 642-651. http://dx.doi.org/10.1172/JCI25705

[82] LUGASSY C, PÉAULT B,WADEHRAM, KLEINMAN HK, BARNHILL RL. Could pericytic mimicry represent another type of melanoma cell plasticity with embryonic properties?. Pigment Cell Melanoma Res 2013; 26: 746-754. http://dx.doi. org $/ 10.1111 / \mathrm{pcmr} .12120$

[83] LUGASSY C, WADEHRA M,LIX, CORSELLI M, AKHAVAND et al. Pilot study on „pericytic mimicry“ and potential embryonic/ stem cell properties of angiotropic melanoma cells interacting with the abluminal vascular surface. Cancer Microenviron 2013 ; 6: 19-29. http://dx.doi.org/10.1007/s12307-012-0128-5

[84.] DOMEV H, MILKOV I, ITSKOVITZ-ELDOR J, DAR A. Immunoevasive pericytes from human pluripotent stem cells preferentially modulate induction of allogeneic regulatory $\mathrm{T}$ cells. Stem Cells Transl Med 2014; 3: 1169-1181. http://dx.doi. org/10.5966/sctm.2014-0097

[85] PIEPER C, MAREK JJ, UNTERBERG M, SCHWERDTLE T, GALLA HJ. Brain capillary pericytes contribute to the immune defense in response to cytokines or LPS in vitro. Brain Res 2014; 1550: 1-8. http://dx.doi.org/10.1016/j. brainres.2014.01.004

[86] OCHS K, SAHM F, OPITZ CA, LANZ TV, OEZEN I et al. Immature mesenchymal stem cell-like pericytes as mediators of immunosuppression in human malignant glioma. J Neuroimmunol 2013; 265: 106-116. http://dx.doi.org/10.1016/j. jneuroim.2013.09.011

[87] KHASRAW M, AMERATUNGA M, GROMMES C. Bevacizumab for the treatment of high-grade glioma: an update after Phase III trials. Expert Opin Biol Ther 2014; 14: 729-740. http://dx.doi.org/10.1517/14712598.2014.898060

[88] NAGY JA, CHANG SH, SHIH SC, DVORAK AM, DVORAK HF. Heterogeneity of the tumor vasculature. Semin Thromb Hemost 2010; 36: 321-331. http://dx.doi.org/10.1055/s-0030$\underline{1253454}$

[89] ZHAO W, GUO MX, XIANG DM, ZHOU J. Effects of pericytes on the leakage of rat corneal neovascularization. Zhonghua Yi Xue Za Zhi 2013; 93: 2164-2166.

[90] GOEL S, DUDA DG, XU L, MUNN LL, BOUCHER Y et al. Normalization of the vasculature for treatment of cancer and other diseases. Physiol Rev 2011; 91: 1071-1121. http://dx.doi. org/10.1152/physrev.00038.2010
[91] CARMELIET P, JAIN RK. Principles and mechanisms of vessel normalization for cancer and other angiogenic diseases. Nat Rev Drug Discov 2011; 10: 417-427. http://dx.doi. org/10.1038/nrd3455

[92] AGRAWAL V, MAHARJAN S, KIM K, KIM NJ, SON J et al. Direct endothelial junction restoration results in significant tumor vascular normalization and metastasis inhibition in mice. Oncotarget 2014; 5: 2761-2777. http://dx.doi.org/10.18632/ oncotarget.1942

[93] WEISSHARDT P, TRARBACH T, DURIG J, PAUL A, REIS $\mathrm{H}$ et al. Tumor vessel stabilization and remodeling by antiangiogenic therapy with bevacizumab. Histochem Cell Biol 2012; 137: 391-401. http://dx.doi.org/10.1007/s00418-011$\underline{0898-8}$

[94] MCCARTY MF, SOMCIO RJ, STOELTZING O, WEY J, FAN F et al. Overexpression of PDGF-BB decreases colorectal and pancreatic cancer growth by increasing tumor pericyte content. J Clin Invest 2007; 117: 2114-2122. http://dx.doi. org/10.1172/JCI31334

[95] FALCON BL, HASHIZUME H, KOUMOUTSAKOS P, CHOU J, BREADY JV et al. Contrasting actions of selective inhibitors of angiopoietin-1 and angiopoietin-2 on the normalization of tumorblood vessels. Am J Pathol 2009; 175: 2159-2170. http://dx.doi.org/10.2353/ajpath.2009.090391

[96] PAUlsSON J, SJOBlOM T, MICKE P, PONTEN F, LANDBERG G et al. Prognostic significance of stromal platelet-derived growth factor beta-receptor expression in human breast cancer. Am J Pathol 2009; 175: 334-341. http:// dx.doi.org/10.2353/ajpath.2009.081030

[97] HAGGLOF C, HAMMARSTEN P, JOSEFSSON A, STATTIN P, PAULSSON J et al. Stromal PDGFRbeta expression in prostate tumors and non-malignant prostate tissue predicts prostate cancersurvival. PLoS One 2010; 5: e10747. http:// dx.doi.org/10.1371/journal.pone.0010747

[98] CHUTE JP, HIMBURG HA. Imatinib tackles lymphoma via the PDGFR $\beta+$ pericyte. Blood 2013; 121: 5107-5108. http:// dx.doi.org/10.1182/blood-2013-05-501205

[99] TSAO AS, LIU S, FUJIMOTO J, WISTUBA II, LEE JJ et al. Phase II trials of imatinib mesylate and docetaxel in patients with metastatic non-small cell lung cancer and headand neck squamous cell carcinoma. J Thorac Oncol 2011; 6: 2104-2111. http://dx.doi.org/10.1097/JTO.0b013e31822e7256

[100] RAYMOND E, BRANDES AA, DITTRICH C, FUMOLEAU P, COUDERT B et al. Phase II study of imatinib in patients with recurrent gliomas of various histologies: a European Organisation for Research and Treatment of Cancer Brain Tumor Group Study. J Clin Oncol 2008; 26: 4659-4665. http:// dx.doi.org/10.1200/JCO.2008.16.9235

[101] TAEGER J, MOSER C, HELLERBRAND C, MYCIELSKA ME, GLOCKZIN G et al. Targeting FGFR/PDGFR/VEGFR impairs tumor growth, angiogenesis, and metastasis by effects on tumor cells,endothelial cells, and pericytes in pancreatic cancer. Mol Cancer Ther 2011; 10: 2157-2167. http://dx.doi. org/10.1158/1535-7163.MCT-11-0312

[102] SENNINO B. Two is better than one: benefits of VEGF and PDGF inhibition in ovarian cancer. Cancer Biol Ther 2010; 9: 183-185. http://dx.doi.org/10.4161/cbt.9.3.11117 
[103] KUHNERT F, TAM BY, SENNINO B, GRAY JT, YUAN J et al. Soluble receptor-mediated selective inhibition of VEGFR and PDGFRbeta signaling during physiologic and tumor angiogenesis. Proc Natl Acad Sci USA 2008 ; 105 : 10185-10190. http://dx.doi.org/10.1073/pnas.0803194105

[104] ABOU-ALFA GK, JOHNSON P, KNOX JJ, CAPANU $\mathrm{M}$, DAVIDENKO I et al. Doxorubicin plus sorafenib vs doxorubicin alone in patients with advanced hepatocellular carcinoma: arandomized trial. JAMA 2010; 304: 2154-2160. http://dx.doi.org/10.1001/jama.2010.1672

[105] RAYMOND E, DAHAN L, RAOUL JL, BANG YJ, BORBATH I et al. Sunitinib malate for the treatment of pancreatic neuroendocrine tumors. N Engl J Med 2011; 364: 501-513. http:// dx.doi.org/10.1056/NEJMoa1003825

[106] KOEBERLE D, MONTEMURRO M, SAMARAS P, MAJNO $\mathrm{P}$, SIMCOCK $\mathrm{M}$ et al. Continuous Sunitinib treatment in patients with advanced hepatocellular carcinoma: a Swiss Group for ClinicalCancer Research (SAKK) and Swiss Association for the Study of the Liver (SASL) multicenter phase II trial (SAKK77/06). Oncologist 2010; 15: 285-292. http://dx.doi. org/10.1634/theoncologist.2009-0316

[107] GROTHEY A, VAN CUTSEM E, SOBRERO A, SIENA S, FALCONE A et al. Regorafenib monotherapy for previously treated metastatic colorectal cancer (CORRECT): an international,multicentre, randomised, placebo-controlled, phase 3 trial. Lancet 2013; 381: 303-312. http://dx.doi. org/10.1016/S0140-6736(12)61900-X

[108] NisAnCIOGLU MH, BETShOLTZ C, GENOVE G. The absence of pericytes does not increase the sensitivity of tumor vasculature to vascular endothelial growth factor-A blockade. Cancer Res 2010; 70: 5109-5115. http:// dx.doi.org/10.1158/0008-5472.CAN-09-4245
[109] WANG S, CAO C, CHEN Z, BANKAITIS V, TZIMA E et al. Pericytes regulate vascular basement membrane remodeling and govern neutrophil extravasation during inflammation. PLoS One 2012; 7: e45499. http://dx.doi.org/10.1371/journal. pone.0045499

[110] RHETT JM, JOURDAN J, GOURDIE RG. Connexin 43 connexon to gap junction transition is regulated by zonula occludens-1. Mol Biol Cell 2011; 22: 1516-1528. http://dx.doi. org/10.1091/mbc.E10-06-0548

[111] MCGUIRE PG, RANGASAMY S, MAESTAS J, DAS A. Pericyte derived sphinogosine 1-phosphate induces the expression of adhesion proteins and modulates the retinal endothelial cell barrier. Arterioscler Thromb Vasc Biol 2011; 31: e107-e115. http://dx.doi.org/10.1161/ATVBAHA.111.235408

[112] JO DH, KIM JH, HEO JI, KIM JH, CHO CH. Interaction between pericytes and endothelial cells leads to formation of tight junction in hyaloid vessels. Mol Cells 2013; 36: 465-471. http://dx.doi.org/10.1007/s10059-013-0228-1

[113] SHIMIZU F, SANO Y, ABE MA, MAEDA T, OHTSUKI S et al. Peripheral nerve pericytes modify the blood-nerve barrier function and tight junctional molecules through the secretion of various soluble factors. J Cell Physiol 2011; 226: 255-266. http://dx.doi.org/10.1002/jcp.22337

[114] RUAN J, LUO M, WANG C, FAN L, YANG SN et al. Imatinib disrupts lymphoma angiogenesis by targeting vascular pericytes. Blood 2013; 121:5192-5202. http://dx.doi.org/10.1182/ blood-2013-03-490763

[115] GUAN YY, LUAN X, XU JR, LIU YR, LU Q et al. Selective eradication of tumor vascular pericytes by peptide-conjugated nanoparticles for antiangiogenic therapy of melanoma lung metastasis. Biomaterials 2014; 35: 3060-3070. http://dx.doi. org/10.1016/j.biomaterials.2013.12.027 